\title{
The benthic macroinvertebrate assemblages in the Zegzel-Cherraa, a partly-temporary river system, Eastern Morocco
}

\author{
A. Maamri ${ }^{1}$, E. Pattee $2 *$, S. Dolédec ${ }^{2}$, H. Chergui ${ }^{3}$ \\ ${ }^{1}$ Hydrobiologie \& Ecologie Générale, Faculté des Sciences, Université Mohamed I, B.P. 524, Oujda, Morocco. \\ 2 UMR CNRS 5023 Ecologie des Hydrosystèmes Fluviaux, Université Claude Bernard-Lyon1, F-69622 Villeurbanne Cedex, France. \\ ${ }^{3}$ Hydrobiologie \& Ecologie Générale, Faculté des Sciences Dhar-el-Mehraz, B.P. 1796, Fes-Atlas, Morocco.
}

\begin{abstract}
Perennial Oued Zegzel and temporary Oued Cherraa are parts of the same watercourse. Coinertia analysis showed the clear distinction between these two parts and the close relationship of the faunal assemblages with the characteristics of the water. The headwater course of the Zegzel is covered with dense terrestrial vegetation whose debris were consumed by abundant shredders dominated by the prosobranch Melanopsis praemorsa. The lower course of the Zegzel has sparse riparian vegetation and much fine detritus, and collectors such as Ecdyonurus rothschildi, Caenis luctuosa, the Diptera Corynoneurinae and Tanytarsini, occurred. In contrast, dry, flowing-, and standing-water periods succeed each other in the Cherraa and terrestrial vegetation often grows in its bed. M. praemorsa was replaced by the air-breathing pulmonate Physa acuta, accompanied by the adults and larvae of flying insects. However many shredders did not develop on the abundant plant litter. The short length of the submersion period was probably responsible for this lack of efficiency in the exploitation of such a non-limiting food resource.
\end{abstract}

Keywords : perennial stream, temporary stream, functional groups.

\section{Introduction}

Temporary watercourses are common in semid-arid regions such as Eastern Morocco. Their temporary flow is due to the characteristic precipitation under Mediterranean climate and often to the karstic substratum. Moreover, demographic expansion and urbanisation, spring harnessing and the development of impervious surfaces have modified water flow and restrained the feeding of aquifers, thus causing the recent transformation of perennial streams and rivers into summer-dry wadis (e.g. Gasith \& Resh 1999). In temporary streams, the main factors influencing the aquatic assemblages include the frequency and duration of the disturbance events and their predictability (Stanley et al. 1997, Gasith \& Resh 1999), whether these streams are Alpine (Ruegg \& Robinson 2004), karstic

\footnotetext{
* Corresponding author :

E-mail: ec.pattee@wanadoo.fr
}

(Meyer et al. 2003), prairie (Hill et al. 1988, Miller \& Golladay 1996), desert (Stanley et al. 1997) or Mediterranean (Bottorff \& Knight 1988, Touabay et al. 2002, Beauchard et al. 2003, Muñoz 2004). Generally, individual abundance and taxonomic richness and diversity were found to be greater in permanent than in neighbouring temporary streams (Williams 1996, Meyer \& Meyer 2000, Touabay et al. 2002, Muñoz 2004) and these values occasionally decreased with shorter presence of the water (Meyer et al. 2003). Plant litter breakdown activity usually showed similar trends (e.g. Herbst \& Reice 1982, Hill et al. 1988, Gurtz \& Tate 1988) in relation with shredder scarcity in temporary streams (Tate \& Gurtz 1986, Gasith \& Resh 1999) though opposite results were also presented in the literature (Gurtz \& Tate 1988, Muñoz 2004).

In Morocco, and despite their overwhelming occurrence, temporary waterbodies such as wadis, dayas, gueltas, swamps... (Marque 1986, Metge 1986, Ramdani 1986, El Khiati 1987, Maamri et al. 1997a and b, 1998, 1999, Chergui et al. 1999) have been less inves- 
tigated than permanent waterbodies such as streams, rivers, and lakes. The aim of the present paper is to describe and compare the aquatic macroinvertebrate assemblages and their functional categories in the upstream permanent course and in the temporary downstream course of one river, considering dates and duration of water flow and the available food resources.

\section{Material and methods}

\section{The Zegzel-Cherraa system}

Oued Zegzel (the upstream course) and Oued Cherraa (the downstream course of the same river) flow down from the Beni-Snassen mountain range into larger Oued Moulouya which opens into the Mediterranean Sea (Maamri et al. 1994, Berrahou et al. 2001) (Fig. 1). In Winter, Oued Cherraa is partly fed by Oued Zegzel and partly by surface runoff and the rise of the aquifer after heavy rain. In the warm season, the heat and evaporation dry it out completely in some sections or leave a few isolated pools in others. The five sites described in Maamri et al (1997a, 1998 and 2001) were considered, two of them in the permanent Zegzel upper course, the third a permanent pool in the temporary course of the Cherraa and the last two in its alternately dry and flooded bed (see Fig. 4). Hence three sites were permanent, site 1 was overgrown, its discharge was small and its current fast, site 2 was more open with higher discharge and slower current. Site 3 was standing during almost 10 months every year and flowed with the river the rest of the time. Sites 4 and 5 were temporary, flowed for a few months, then became

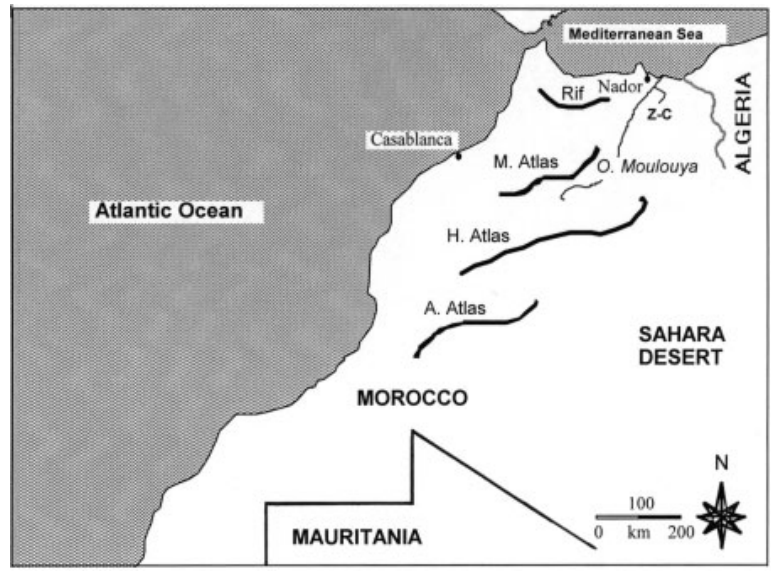

Fig. 1. Location of the study sites in Morocco. ZC = Zegzel Cherraa flowing into Oued Moulouya, M. Atlas = Middle Atlas, H. Atlas $=$ High Atlas, A. Atlas = Anti-Atlas. sets of standing pools before completely drying out. Site 5 had much terrestrial vegetation in its bed (Table 1, upper part ).

\section{Water sampling}

Fifteen factors were considered monthly when collecting the fauna from October 1994 to September 1995.

Spot measurements of water temperature were performed in the field between 9 and 11 a.m. with a mercury thermometer. Temperature was measured at open and shaded parts of each site so as to obtain a representative average value.

The other measurements were made on water carried to the laboratory in an insulated box. Water $\mathrm{pH}$ was evaluated with a WTW pH 521 meter. Conductivity at $25^{\circ} \mathrm{C}$ was measured with a Consort conductimeter. Fine Suspended Matter (FSM) and Fine Suspended Organic Matter (FSOM) were evaluated after filtering on pre-weighed GF/F Whatman filters, then drying $\left(105^{\circ} \mathrm{C}, 24 \mathrm{~h}\right)$ and combustion $\left(525^{\circ} \mathrm{C}, 3 \mathrm{~h}\right)$, respectively. Dissolved Organic Matter (DOM) was evaluated with a Dohrman CD 80 carbon analyser. Ammonium ion concentration was evaluated according to AFNOR T-90-015 (1956b), nitrites according to AFNOR T-90013 (1956a), nitrates to AFNOR T-90-012 (1952a), orthophosphates to AFNOR T-90-023 (1963), chlorides to AFNOR T-90-014 (1952b), sulphates to AFNOR T90-009 (1954). Calcium, magnesium, and sodium were evaluated with a Varian atomic absorption spectrophotometer.

\section{Fauna sampling}

The fauna was collected each month from October 1994 to September 1995 from the three permanent sites, and from temporary sites 4 and 5 when they were flooded. A Surber net with $0.4 \mathrm{~mm}$ meshes that sampled a surface of $0.1 \mathrm{~m}^{2}$ was used. At each site, four samples were collected from different microhabitats and pooled, thus covering an area of $0.4 \mathrm{~m}^{2}$. Other samples collected with artificial substrates for control at site 3 (Maamri et al. 1995), showed the same composition of the fauna. Small-sized taxa living in the surface sediment such as Tubificidae or Ostracoda were recorded when they were caught but the technique was not adapted to their efficient sampling.

Each sample was placed in a plastic box and the organisms were preserved in $10 \%$ formaldehyde. In the laboratory, the fauna was sorted, identified, counted, and classified among functional feeding groups according to Tachet et al. (2002) and Cummins \& Wilzbach (1985). 
Table 1. Mean characteristics of the five sites ( \pm SD). Flash floods (many $\mathrm{m}^{3} \mathrm{~s}^{-1}$ for short periods) were not taken into account in the evaluation of discharge at the four lower sites. FSM : Fine Suspended Matter. FSOM : Fine Suspended Organic Matter. DOM : Dissolved Organic Matter.

\begin{tabular}{|c|c|c|c|c|c|}
\hline Site & 1-Upstream Zegzel & 2-Downstream Zegzel & 3-Permanent Pool & 4-Upstream Cherraa & 5-Downstream Cherraa \\
\hline Altitude a.s.I. (m) & 435 & 280 & 220 & 200 & 190 \\
\hline Distance from site $1(\mathrm{~km})$ & & 8 & 9 & 11 & 13 \\
\hline Presence of water & permanent & permanent & permanent & temporary & temporary \\
\hline Maximum width (m) & 2 & 30 & $4 \times 6$ & 40 & 100 \\
\hline Discharge $\left(\mathrm{Ls}^{-1}\right)$ & $10-100$ & $90-320$ & - & $0-500$ & $0-700$ \\
\hline Flow $\left(\mathrm{ms}^{-1}\right)$ & 0.75 & 0.25 & occasional & $0-1.00$ & $0-0.60$ \\
\hline Substratum & sand, stones & sand, cobble, boulders & silt, sand & sand, gravel, cobble & pebble, cobble \\
\hline Organic debris & many debris dams & + & +++ & + & ++ \\
\hline Aquatic vegetation & $\begin{array}{c}\text { filamentous algae } \\
\text { Chara }\end{array}$ & $\begin{array}{c}\text { algal film on stones } \\
\text { some filamentous algae } \\
\text { and Chara }\end{array}$ & $\begin{array}{l}\text { Potamogeton } \\
\text { and many other } \\
\text { macrophytes }\end{array}$ & $\begin{array}{c}\text { filamentous algae } \\
\text { in pools while } \\
\text { drying out }\end{array}$ & some algae on stones \\
\hline Riparian vegetation & overhanging & sparse & dense & sparse & dense and in the bed itself \\
\hline Temperature $\left({ }^{\circ} \mathrm{C}\right)$ & $19.7 \pm 6.0$ & $16.6 \pm 5.0$ & $21.7 \pm 9.0$ & $26.4 \pm 3.9$ & $26.6 \pm 4.0$ \\
\hline $\mathrm{pH}$ & $7.5 \pm 0.2$ & $7.6 \pm 0.1$ & $7.3 \pm 0.4$ & $7.5 \pm 0.4$ & $7.5 \pm 0.01$ \\
\hline Conductivity ( $\mu \mathrm{S} \mathrm{cm}^{-1}$ at $25^{\circ} \mathrm{C}$ ) & $202 \pm 12$ & $309 \pm 19$ & $405 \pm 124$ & $470 \pm 74$ & $442 \pm 82$ \\
\hline $\mathrm{FSM}\left(\mathrm{mg} \mathrm{L}^{-1}\right)$ & $2.3 \pm 1.2$ & $4.6 \pm 2.4$ & $23.3 \pm 21.0$ & $63.3 \pm 40.0$ & $88.0 \pm 40.0$ \\
\hline FSOM $\left(\mathrm{mg} \mathrm{L}^{-1}\right)$ & $0.6 \pm 0.7$ & $3.4 \pm 1.9$ & $5.8 \pm 5.4$ & $14.2 \pm 9.1$ & $20.7 \pm 8.4$ \\
\hline $\mathrm{DOM}\left(\mathrm{mg} \mathrm{L}^{-1}\right)$ & $2.3 \pm 2.2$ & $2.9 \pm 2.8$ & $151.3 \pm 72.5$ & $134.3 \pm 71.9$ & $165.6 \pm 126.0$ \\
\hline $\mathrm{Cl}^{-}\left(\mathrm{mg} \mathrm{L}^{-1}\right)$ & $22.2 \pm 3.0$ & $32.7 \pm 3.5$ & $36.4 \pm 17.5$ & $51.6 \pm 15.2$ & $48.8 \pm 18.5$ \\
\hline $\mathrm{SO}_{4}^{-}\left(\mathrm{mg} \mathrm{L}^{-1}\right)$ & $13.4 \pm 0.5$ & $20.6 \pm 1.4$ & $70.3 \pm 17.6$ & $57.1 \pm 15.7$ & $51.8 \pm 18.7$ \\
\hline $\mathrm{NH}_{4}^{+}\left(\mathrm{mg} \mathrm{L}^{-1}\right)$ & $0.03 \pm 0.03$ & $0.02 \pm 0.01$ & $0.02 \pm 0.02$ & $0.02 \pm 0.01$ & $0.02 \pm 0.01$ \\
\hline $\mathrm{NO}^{-}\left(\mathrm{mg} \mathrm{L}^{-1}\right)$ & $0.58 \pm 0.006$ & $0.38 \pm 0.002$ & $0.17 \pm 0.16$ & $0.11 \pm 0.11$ & $0.23 \pm 0.20$ \\
\hline $\mathrm{NO}^{-}\left(\mathrm{mg} \mathrm{L}^{-1}\right)$ & $6.25 \pm 3.50$ & $3.75 \pm 0.80$ & $3.57 \pm 3.00$ & $4.64 \pm 4.00$ & $4.16 \pm 4.00$ \\
\hline $\mathrm{PO}^{--}\left(\mathrm{mg} \mathrm{L}^{-1}\right)$ & $0.18 \pm 0.10$ & $0.16 \pm 0.08$ & $0.14 \pm 0.07$ & $0.17 \pm 0.10$ & $0.20 \pm 0.08$ \\
\hline $\mathrm{Na}^{+}\left(\mathrm{mg} \mathrm{L}^{-1}\right)$ & $32.8 \pm 2.0$ & $24.0 \pm 1.4$ & $85.9 \pm 32.6$ & $75.9 \pm 21.4$ & $72.8 \pm 20.1$ \\
\hline $\mathrm{Ca}^{++}\left(\mathrm{mg} \mathrm{L}^{-1}\right)$ & $59.8 \pm 3.7$ & $48.3 \pm 2.3$ & $88.1 \pm 31.2$ & $62.7 \pm 32.7$ & $47.4 \pm 32.7$ \\
\hline $\mathrm{Mg}^{++}\left(\mathrm{mg} \mathrm{L}^{-1}\right)$ & $28.0 \pm 3.1$ & $20.0 \pm 2.0$ & $45.0 \pm 16.7$ & $24.0 \pm 12.1$ & $21.0 \pm 10.6$ \\
\hline
\end{tabular}

\section{Data analysis}

Physical and chemical variables were treated as annual means by normalised Principal Component Analysis (PCA). The table of the annual mean abundances of invertebrate taxa collected at each site was treated by Correspondence Analysis (COA). To investigate the relationships between the physical and chemical factors and the structure of the stream invertebrate assemblages, we applied co-inertia analysis (Dolédec \& Chessel 1994, Ter Braak \& Verdonschot 1995, Dray et al. 2003). The statistical significance of the link between the two tables was assessed from random permutations on the RV-coefficient, the equivalent for two tables of the usual correlation coefficient (Robert \& Escoufier 1976). Computation and graphical representations were achieved using R freeware http://www.rproject.org/ (Ihaka \& Gentleman 1996). Coinertia analysis and permutation tests are available in the ADE4 package (Chessel et al. 2004).

\section{Results}

\section{Physical and chemical characteristics}

The data are recorded in Table 1 (lower part). As could be expected, conditions were more stable in permanently-flowing Zegzel than in temporary Cherraa. In Figs $2 \mathrm{a}$ and $\mathrm{b}$ the first axis of the statistical analysis almost describes the longitudinal succession of the watercourse. It opposes Zegzel perennial sites 1 and 2 with higher values of nitrogen to Cherraa temporary sites 4 and 5 with higher values of conductivity, dissolved and suspended matter, chlorides and sulphates. The second axis accounts for $\mathrm{pH}$ variations which were in fact small (7.3 - 7.6) and presumably of no great meaning, but $\mathrm{Ca}-\mathrm{Mg}$ hardness discriminates downstream perennial site 2 from the topographically close permanent pool site 3 .

\section{Taxon richness}

The number of taxa decreased along the course of the river with the exception of site 2 whose fauna was 


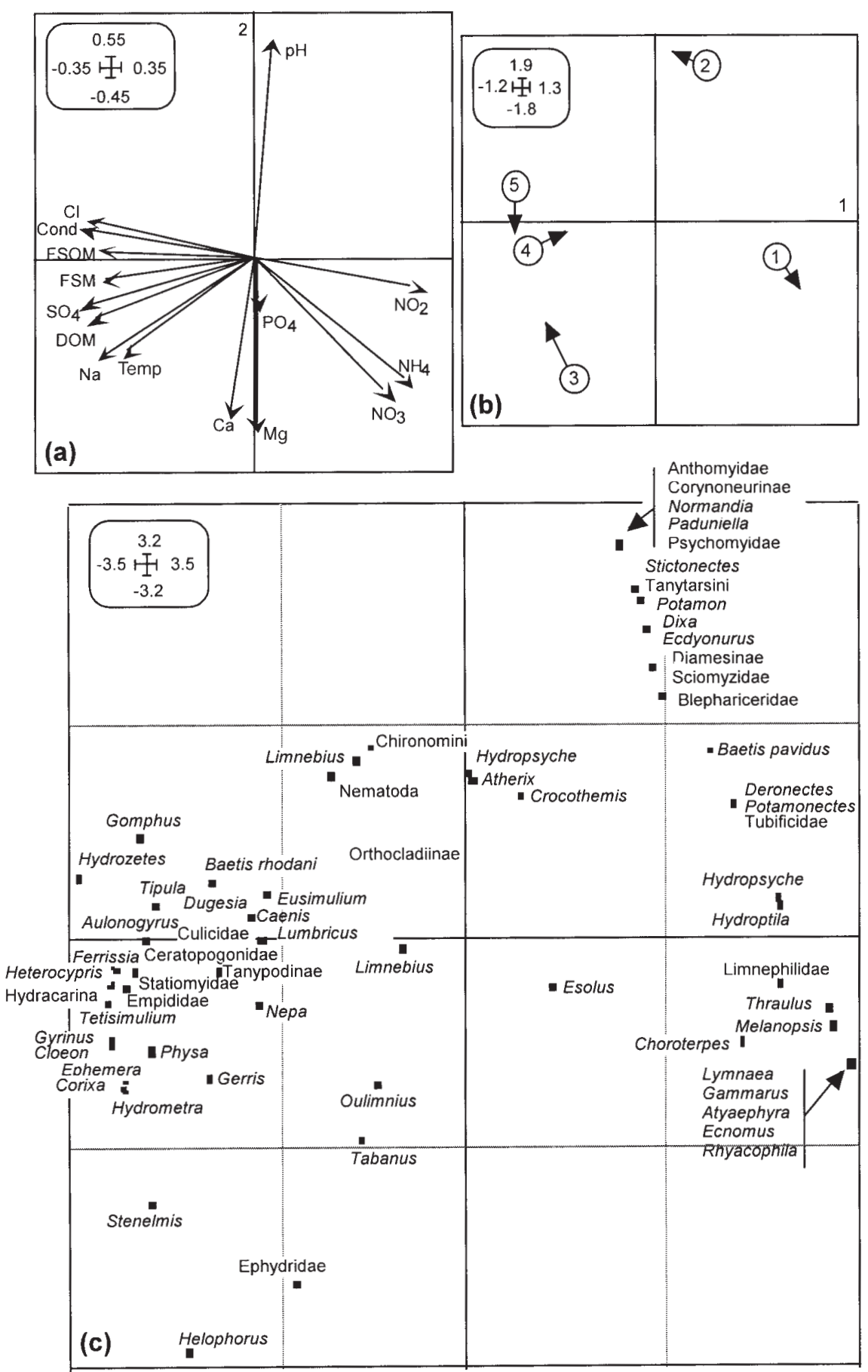

Fig. 2. Coinertia analysis performed between physical and chemical characteristics, and taxon composition. (a) Weight of each environmental variable along the first two axes of the coinertia analysis. Cond $=$ conductivity, FSOM $=$ Fine Suspended Organic Matter, FSM = Fine Suspended Matter, DOM =Dissolved Organic Matter, Temp = mean temperature. Other acronyms are self-understandable. (b) Locations of the five sites according to their environmental positions (circles) and their species compositions (ends of arrows). (c) Scores of each taxon along the first two co-inertia axes. Taxa are placed according to their average distribution at sites located according to their physical and chemical characteristics. 
richer than that of site 1 (Table 2). Individual abundance varied little among sites except at site 1 where $\mathrm{Me}$ lanopsis, Choroterpes, and Limnephilidae were prominent ; small and middle-sized Melanopsis almost covered each of the plant debris. In temporary Cherraa, taxon richness and individual abundance varied simultaneously over the months (Fig. 3) : both were low when the water returned in March then rose to a maximum in June before decreasing and becoming low again in the pools that were drying out in September at site 4. Comparison with neighbouring sites 2 and 3 show that maxima were reached in December-January at the permanent sites but much later at the temporary sites.

Relationship between the composition of the fauna and the environmental conditions

The first two axes of the co-inertia analysis accounted for $91.6 \%$ (axis $1=79.0 \%$; axis $2=12.6 \%$ ) of the total variability of the taxa-by-variables crossed table. The overall correlation between the faunal and environmental data was statistically significant $(\mathrm{RV}=$ $0.887, \mathrm{P}<0.001$ ), which was confirmed by the short length of the arrows connecting the environmental and faunal locations of the sites in Fig. $2 b$.

Certain taxa were only found in small numbers, either because they were actually rare (for instance Atyaephyra and several Coleoptera), or because the technique used was not adapted to their sampling, as explained in the Methods section. The fauna was distributed as follows (Figs 2b and 2c).

In the Zegzel, the larvae of the Ephemeroptera Choroterpes picteti and Thraulus sp. and of the Trichoptera Ecnomus deceptor were characteristic of upstream permanent site 1. The Crustacea Decapoda Potamon edule, the Ephemeroptera larvae Ecdyonurus rothschildi, the Coleoptera Stictonectes lepidus and the larvae of the Diptera Corynoneurinae and Tanytarsini were more abundant at downstream permanent site 2 . Apart from Diptera Ephydridae, the permanent pool had few characteristic species ; the Coleoptera Stenelmis consobrina and the larvae of the Diptera Tabanus sp. were only somewhat more abundant at this site. Both temporary sites 4 and 5 had mostly similar populations including the Ephemeroptera Baetis rhodani and Cloeon dipterum, the Coleoptera Aulonogyrus striatus, and larvae of the Diptera Tipula sp. However, Hydracarinae and Culicidae only colonised the former site and the Diptera Tetisimulium bezzii only the latter.

Last, within Gastropoda the distinction was clearcut : the prosobranch Melanopsis praemorsa only oc-
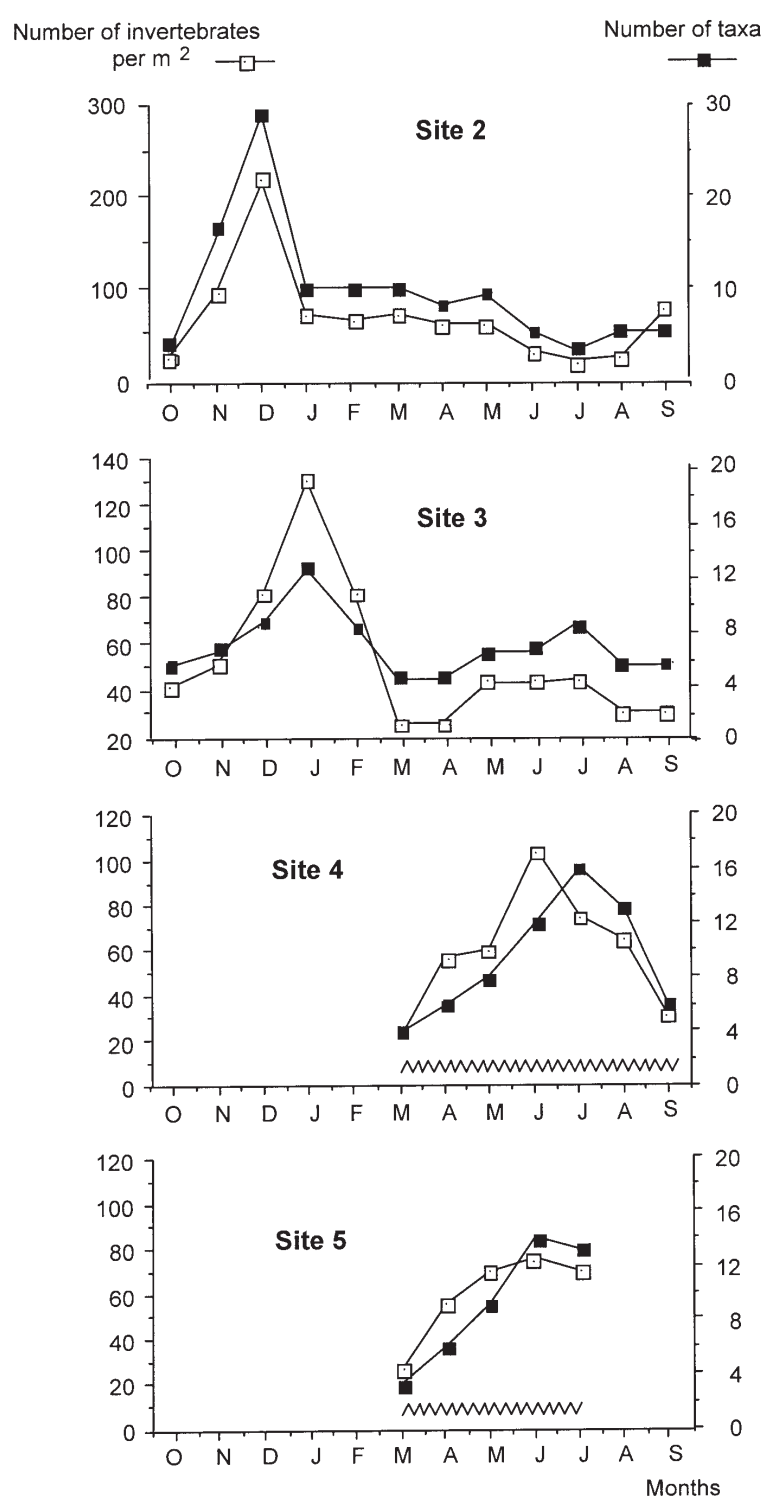

Fig. 3. Temporal changes in aquatic fauna richness and abundance at sites 2 and 3 and in Oued Cherraa during the submersion period (horizontal wavy lines).

curred at the Zegzel perennial sites with a preference for the upstream site while the pulmonates Ferrissia sp. and Physa acuta mainly occupied the Cherraa temporary sites.

\section{Functional Feeding Groups}

Fig. 4 makes it possible to compare the functional groups identified in this study with the stock of plant 
Table 2. List and total abundance (ind. $\mathrm{m}^{-2}$ ) of the macroinvertebrates collected from the five sites of the Zegzel-Cherraa system.

\begin{tabular}{|c|c|c|c|c|c|}
\hline Taxa & Site 1 & Site 2 & Site 3 & Site 4 & Site 5 \\
\hline \multicolumn{6}{|l|}{ Turbellaria Tricladida } \\
\hline Dugesia gonocephala Dugès & 6 & 15 & - & 50 & - \\
\hline \multicolumn{6}{|l|}{ Nemathelminthes } \\
\hline Nematoda & 1 & 10 & - & 6 & 8 \\
\hline \multicolumn{6}{|l|}{ Annelida Oligochaeta } \\
\hline Tubificidae & 2 & 2 & - & - & - \\
\hline Lumbricus sp. & 4 & 3 & 2 & 6 & 15 \\
\hline \multicolumn{6}{|l|}{ Mollusca Gastropoda } \\
\hline Melanopsis praemorsa L. & 405 & 31 & - & - & - \\
\hline Ferrissia sp. & 1 & - & 10 & - & 43 \\
\hline Lymnaea truncatula Müller & 1 & - & - & - & - \\
\hline Physa acuta Drap. & 5 & - & 20 & 60 & 10 \\
\hline \multicolumn{6}{|l|}{ Arachnida } \\
\hline Hydracarina & - & - & - & 10 & - \\
\hline \multicolumn{6}{|l|}{ Crustacea Ostracoda } \\
\hline Heterocypris reptans Baird & - & - & - & 2 & - \\
\hline Hydrozetes sp. & - & - & - & - & 5 \\
\hline \multicolumn{6}{|l|}{ Crustacea Amphipoda } \\
\hline Gammarus sp. & 1 & - & - & - & - \\
\hline \multicolumn{6}{|l|}{ Crustacea Decapoda } \\
\hline Atyaephyra desmaresti Millet & 2 & - & - & - & - \\
\hline Potamon edule Lateille & 1 & 8 & - & - & - \\
\hline \multicolumn{6}{|l|}{ Insecta Ephemeroptera } \\
\hline Baetis pavidus Grandi & 4 & 6 & - & - & - \\
\hline Baetis rhodani Pictet & 3 & 6 & - & 18 & 16 \\
\hline Cloeon dipterum $\mathrm{L}$. & - & - & 9 & 10 & 13 \\
\hline Caenis Iuctuosa Burm. & - & 8 & 5 & 12 & 5 \\
\hline Choroterpes picteti Eaton & 60 & 2 & 1 & 9 & - \\
\hline Thraulus sp. & 8 & 1 & - & - & - \\
\hline Ecdyonurus rothschildi Navas & 2 & 10 & - & - & - \\
\hline Ephemera sp. & - & - & 5 & - & 7 \\
\hline \multicolumn{6}{|l|}{ Insecta Odonata } \\
\hline Crocothemis erythraea Brullé & 1 & 10 & 4 & - & - \\
\hline Gomphus simillimus Selys & - & 1 & - & - & 8 \\
\hline \multicolumn{6}{|l|}{ Insecta Heteroptera } \\
\hline Corixa sp. & - & - & 4 & 10 & - \\
\hline Gerris cinereus Put. & 1 & 1 & 7 & - & 7 \\
\hline Hydrometra stagnorum $\mathrm{L}$. & - & - & 9 & 10 & 6 \\
\hline Nepa sp. & 1 & 3 & 5 & 9 & - \\
\hline \multicolumn{6}{|l|}{ Insecta Coleoptera } \\
\hline Aulonogyrus striatus Fabricius & - & 1 & 1 & 9 & 6 \\
\hline Gyrinus urinator Illiger & - & - & 5 & 8 & 7 \\
\hline Deronectes fairmairei Leprieur & 1 & 1 & - & - & - \\
\hline Stictonectes optatus Seidlitz & 1 & 10 & - & - & - \\
\hline Nebrioporus clarki Wollaston & 1 & 1 & - & - & - \\
\hline Helophorus gr. maritimus & - & - & 1 & - & - \\
\hline
\end{tabular}


Table 2. List and total abundance (ind. $\mathrm{m}^{-2}$ ) of the macroinvertebrates collected from the five sites of the Zegzel-Cherraa system. (continued).

\begin{tabular}{|c|c|c|c|c|c|}
\hline Taxa & Site 1 & Site 2 & Site 3 & Site 4 & Site 5 \\
\hline Limnebius fretalis Peyerimhoff & - & 1 & 1 & - & - \\
\hline Limnebius sp. & - & 1 & - & 1 & - \\
\hline Esolus pygmaeus Müller & 1 & 1 & 1 & - & - \\
\hline Normandia villosocostata Reiche & - & 1 & - & - & - \\
\hline Oulimnius fuscipes Reiche & - & 3 & 6 & - & - \\
\hline $\begin{array}{l}\text { Stenelmis consobrina Dufour } \\
\text { Insecta Trichoptera }\end{array}$ & - & - & 9 & 6 & - \\
\hline Ecnomus deceptor Mcl. & 6 & - & - & - & - \\
\hline Hydroptila vectis Curtis & 9 & 4 & - & - & - \\
\hline Hydropsyche lobata Mcl. & 15 & 7 & - & - & - \\
\hline Hydropsyche maroccana Navas & 6 & 20 & - & 14 & - \\
\hline Paduniella vandeli Décamps & - & 1 & - & - & - \\
\hline Rhyacophila sp. & 1 & - & - & - & - \\
\hline Limnephilidae & 50 & 10 & 1 & 2 & - \\
\hline \multicolumn{6}{|l|}{ Insecta Diptera } \\
\hline Anthomyidae & - & 1 & - & - & - \\
\hline Atherix sp. & 1 & 11 & 3 & 3 & - \\
\hline Empididae & - & 1 & 7 & 3 & 19 \\
\hline Ephydridae & 1 & 1 & 14 & - & - \\
\hline Sciomyzidae & 1 & 3 & - & - & - \\
\hline Stratiomyidae & - & 1 & 4 & - & 12 \\
\hline Tabanus sp. & 1 & 2 & 6 & - & - \\
\hline Blephariceridae & 2 & 5 & - & - & - \\
\hline Ceratopogonidae & 1 & 5 & 7 & 12 & 26 \\
\hline Chironomidae Chironominae & 1 & 50 & - & 30 & 14 \\
\hline Chironomidae Corynoneurinae & - & 7 & - & - & - \\
\hline Chironomidae Diamesinae & 1 & 3 & - & - & - \\
\hline Chironomidae Orthocladiinae & - & 9 & 4 & 7 & 1 \\
\hline Chironomidae Tanypodinae & 4 & 4 & 8 & 9 & 20 \\
\hline Chironomidae Tanytarsini & 6 & 60 & - & - & - \\
\hline Culicidae & 1 & 3 & 1 & 16 & - \\
\hline Dixa sp. & 1 & 5 & - & - & - \\
\hline Psychodidae & - & 2 & - & - & - \\
\hline Eusimulium latinum Rubsov & 1 & 10 & 6 & 9 & 15 \\
\hline Tetisimulium bezzii Corti & - & - & 6 & - & 17 \\
\hline Tipula sp. & - & 3 & 1 & 12 & 20 \\
\hline Number of individuals & 622 & 365 & 173 & 353 & 300 \\
\hline Number of taxa & 41 & 50 & 32 & 28 & 23 \\
\hline
\end{tabular}

litter deposited by the riparian, semi-aquatic, and aquatic vegetation in the Zegzel-Cherraa system according to Maamri et al. (1997b). No great number of shred- ders was found below site 1 but collectors were numerous at site 2. Most scrapers appeared at site 3 and below. 


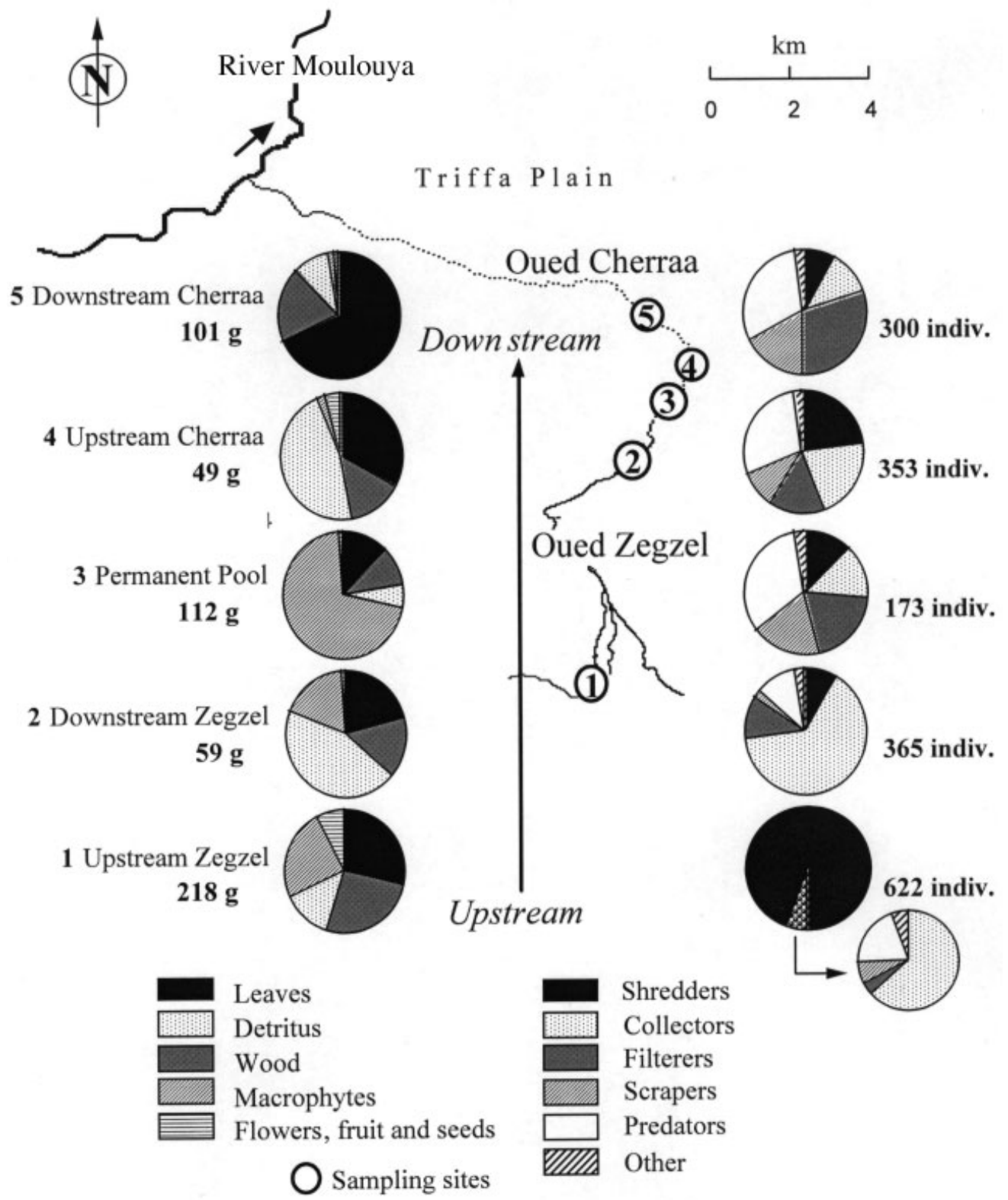

Fig. 4. Coarse Particulate Organic Matter (left, in g. $\mathrm{m}^{-2} \cdot \mathrm{y}^{-1}$ after Maamri et al 1997b) and number of individuals in functional groups (right, individuals per $\mathrm{m}^{2}$ according to Table 2 ) at the five sampling sites.

\section{Discussion}

First of all, one should keep in mind that the information on the environmental and faunal data covers an annual cycle at the permanent sites but only the period of submersion at the temporary sites.

As expected, Oueds Zegzel and Cherraa were dis- tinct through their physical and chemical conditions. Numbers of taxa and numbers of individuals were lower in temporary Cherraa where the aquatic environment was harsher. When the water flowed again, a gradual colonisation occurred during the first three months. Recovery was slower than in the temperate English stream investigated by Ledger \& Hildrew 
(2001) where some 600 individuals. $\mathrm{m}^{-2}$ were already present on the third day and where numbers peaked after 38 days. But the dry period was shorter in England than in Morocco (some two months versus some 5-7 months, respectively). Under more similar climates, recovery took only two weeks in two intermittent Australian streams (Boulton \& Lake 1992) but it was gradual in a Spanish stream after 3 months' drought (Otermin et al. 2002). Presumably, the longer the dry period the slower the recovery.

In the Cherraa, part of the fauna such as Dugesia gonocephala, Lumbricus sp., Ferrissia sp., Physa acuta, probably came out from the sediment where they had survived during the dry months. Other taxa drifted down from upstream (Hydropsyche maroccana), flew over from permanent refugia (Corixa sp., Coleoptera Gyrinidae, several Ephemeroptera and Diptera), or even reproduced on the spot (Diptera Chironomidae and Culicidae). Indeed, many species among the Diptera Chironomidae, Culicidae, and Tipulidae, are known to have a quick and short larval development which often coincides with the hydrological cycle (Légier \& Talin 1979, Ledger \& Hildrew 2001).

While the pools were drying out in the Cherraa, the few surviving taxa (Gerris and Chironominae) resisted heat $\left(32^{\circ} \mathrm{C}\right.$ at upstream temporary site 4 in August), water stagnation, and high concentrations of dissolved matter $\left(200 \mathrm{mg} \mathrm{L}^{-1}\right.$ at the upstream site, even $300 \mathrm{mg}$ $\mathrm{L}^{-1}$ at the downstream one), a common feature in $\mathrm{Me}-$ diterranean and tropical temporary waterbodies. In contrast, the FSOM which was abundant at first in the flowing water (100 - $\left.120 \mathrm{mg} \mathrm{L}^{-1}\right)$ and exploited by $\mathrm{Hy}$ dropsyche maroccana and Simuliidae became scarce in the pools (Maamri et al. 1997b).

The taxon composition was significantly related to the physical and chemical variables selected. Among the gastropods, the dissolved-oxygen-breathing Melanopsis praemorsa lived in permanent Oued Zegzel whereas the air-breathing Physa acuta survived the drought in temporary Oued Cherraa. Ferrissia also breathes dissolved oxygen but it presumably survived in the damp sediments of the Cherraa : Tachet et al. (2000) mentioned the occurrence of drought-surviving forms with a septum across their shell, which was also witnessed in Cherraa individuals.

Unexpectedly, the permanent pool which is alternately standing and flowing had little characteristic fauna. In connection with its amount of macrophyte litter, scraper pulmonate gastropods and Diptera Ephydridae appeared but never dominated, nor did shredders. In relation with the water cycle, the Heteroptera Hydro- metra, Gerris, and Corixa, and the larvae of the Ephemeroptera Cloeon dipterum prevailed during stagnation, the Coleoptera Elmidae, the larvae of Diptera Simuliidae and Tabanidae during flow. In fact, according to the first co-inertia axis in Fig. 2b, this assemblage was connected with those of the temporary sites which passed through the three phases flow, stagnation, and drought. Nevertheless Baetis which was present at all other sites was not found here.

At both temporary Cherraa sites, Baetis rhodani was characteristic of the flowing phase and Aulonogyrus striatus skimmed the surface of the drying-out pools. The nets of Hydropsyche maroccana (upstream site 4) and the premandibular fans of Eusimulium latinum and Tetisimulium bezzii (downstream site 5) were only functional while the water was flowing. Apart from the larvae of Tipula, none of the invertebrates seemed to be characteristic of temporary sites and, as questioned by Williams (1996), one can wonder whether constraints in these temporary waters are actual facts for the invertebrate fauna or simply human perception of them.

Shredder abundance is often connected with the density of the riparian vegetation (Ryder \& Scott 1988). And indeed, at upstream permanent site 1 , the considerable input of plant litter was fed upon by a dense population of shredders dominated by $M$. praemors which occupied the niche of the gammarids present in other similar watercourses (Touabay et al. 2002). Some shredding Ephemeroptera and Trichoptera also occurred. In contrast, the organic material at downstream permanent site 2 amounted approximately to one fourth that of the upstream site and contained much unidentified plant detritus. Fine matter was also washed down from upstream : fine particulate organic matter deposited in the sediment amounted to $166 \mathrm{~g} \cdot \mathrm{m}^{-2} \cdot \mathrm{y}^{-1}$ versus $39 \mathrm{~g} \cdot \mathrm{m}^{-2} \cdot \mathrm{y}^{-1}$ upstream (Maamri et al. 1995 and 1996). This fine organic matter was exploited by collectors such as Ecdyonurus rothschildi, Caenis luctuo$s a$, the Diptera Corynoneurinae and Tanytarsini. As stressed by Cummins et al. (1989) and Vannote et al (1980), the riparian zone and its plant litter had a major influence on the structure of the benthic communities with the usual downstream reduction in the size of the organic particles owing to physical and biological processing, and the replacement of coarse-particle shredders by fine-particle collectors.

Despite the presence of a few large plant-litter shredding Tipula sp. larvae whose biomass and consumption are greater than only suggested by their numbers, the shredding assemblage at site 5 was not in proportion to the stock of dead leaves. Temporary streams are 
young and unstable ecosystems and disturbance plays a major role in structuring their communities (Légier \& Talin 1979, Boulton \& Lake, 1992). Each time the water returns, a benthic assemblage develops and gradually becomes more complex (e.g. Williams 1996), but, when the flowing phase does not last long enough, most often this succession does not reach a stable state because it is interrupted by stagnation and gradual drying out of the water (Miller \& Golladay 1996, Touabay et al. 2002). This explains the lack of numerous shredders despite the abundance of leaf litter at site 5. Altogether, Kirby et al (1983), Tate \& Gurtz (1986), and Gasith \& Resh (1999) also stressed the lower abundance and/or smaller role played by shredders in temporary watercourses.

As a consequence, this organic matter which was also little exploited by the terrestrial fauna (Maamri et al. 1997a) is presumably carried downstream with the water flow.

During the period of investigation, complete drought lasted from October to early March; in 1998/99 it lasted from September to early January (Maamri et al. 2001). In Oued Cherraa it seems to occur later than in many temporary streams. For instance, Arab et al. (2004) mention the absence of flow from May to November in the nearby West-Algerian Oued Chelif. This suggests a great stock of water in the Beni-Snassen mountains and/or in the Zegzel-Cherraa aquifer, a stock that may be long to drain and slow to refill.

Hence, during the main period of litter fall the Cherraa was dry. The development of the aquatic community started not from deciduous leaf fall as in the Zegzel and permanent pool but from the first flow of the water. Only then did the shredders appear, followed by the fine particle consumers (collector-gatherers and filterers). The paradoxical presence of more shredders at the upstream Cherraa site than downstream as soon as the water returned may be due to the shorter submersion period, to drift from the Zegzel over $1.5 \mathrm{~km}$ and/or to the coarser structure of the substratum which retains more detritus and makes the penetration and survival of the fauna in the hyporheic zone more easy (Strommer \& Smock 1989, Williams 1996).

\section{Conclusion}

There was a statistical difference between both parts of the river which appeared as well in the physico-chemical as in the faunal data, and a close relationship of each community with its environment. The temporary aquatic communities began developing some five months later than the permanent communities But presumably owing to the length of the dry period, they were unable to achieve a complete exploitation of the resources available. Their annual cycle was based on the period of flow and not on seasonal deciduous litter fall as it was in the permanent part of the river.

\section{References}

AFNOR T90-009 1954. - Dosage des ions sulfates. Essais des eaux. Association Française de Normalisation, Paris, 2 p.

AFNOR T90-012 1952a. - Dosage colorimétrique des ions nitrate. Essais des eaux. Association Française de Normalisation, Paris, $2 \mathrm{p}$.

AFNOR T90-013 1956a. - Dosage colorimétrique des ions nitrite. Essais des eaux. Association Française de Normalisation, Paris $3 \mathrm{p}$.

AFNOR T90-014 1952b. - Dosage des ions chlore. Essais des eaux. Association Française de Normalisation, Paris, 2 p.

AFNOR T90-015 1956b. - Dosage colorimétrique des ions ammonium. Essai des eaux. Association Française de Normalisation, Paris, 4 p.

AFNOR T90-023 1963. - Dosage spectrophotométrique des orthophosphates et des polyphosphates. Association Française de Normalisation, Paris, 5 p.

Arab A., Lek S., Lounaci A. \& Park Y.S. 2004. - Spatial and temporal patterns of benthic invertebrate communities in an intermittent river (North Africa). Ann. Limnol. - Int. J. Lim., 40, 317-327.

Beauchard O., Gagneur J. \& Brosse S. 2003. - Macroinvertebrate richness patterns in North African streams. J. Biogeography, 30, 1821-1833.

Berrahou A., Cellot B. \& Richoux P. 2001. - Distribution longitudinale des macroinvertébrés benthiques de la Moulouya et de ses principaux affluents (Maroc). Ann. Limnol. - Int. J. Lim., 37, 223 235.

Bottorff R.L. \& Knight N.K. 1988. - Functional organization of macroinvertebrate communities in two first order Californian streams : comparison of perennial and intermittent flow conditions. Verh. Internat. Verein. Limnol., 23, 1147-1152.

Boulton A.J. \& Lake P.S. 1992. - The ecology of two intermittent streams in Victoria, Australia. II. Comparison of faunal composition between habitats, rivers and years. Freshwat. Biol., 27, 99121.

Chergui H., Pattee E., Essafi K. \& Alaoui Mhamdi M. 1999. - Moroccan limnology. Pages 235-330 in Limnology in Developing Countries 2. Wetzel R.G. \& Gopal B. (eds). Internat. Sci. Publs, New Delhi.

Chessel D., Dufour A.B. \& Thioulouse J. 2004. - The ade4 package - I : One-table methods. R News, 4, 5-10.

Cummins K.W. \& Wilzbach M.A. 1985. - Field procedures for analysis of functional feeding groups of stream invertebrates. Appalachian Environmental Laboratory, University of Maryland, Frostburg. Cont. $\mathrm{N}^{\circ} 1611,18 \mathrm{p}$.

Cummins K.W., Wilzbach M.A., Gates D.M., Perry J. \& Talliaferro W.B. 1989. - Shredders and riparian vegetation. BioScience, 39, $24-30$.

Dolédec S. \& Chessel D. 1994. - Co-inertia analysis: an alternative method for studying species-environment relationships. Freshwat. Biol., 31, 277-293.

Dray S., Chessel D. \& Thioulouse J. 2003. - Co-inertia analysis and the linking of ecological data tables. Ecology, 84, 3078-3089.

El Khiati N. 1987. - Les Characées (macroalgues) du Maroc : biotypologie dans les eaux continentales et production dans les dayas 
(mares temporaires). Thesis of University Marseille-I, $115 \mathrm{pp}$

Gasith A. \& Resh H. 1999. - Streams in Mediterranean climate regions: abiotic influences and biotic responses to predictable seasonal events. Ann. Rev. Ecol. Syst., 30, 51-81.

Gurtz M.E. \& Tate C.M. 1988. - Hydrologic influences on leaf decomposition in a channel and adjacent bank of a gallery forest stream. Amer. Midl. Nat., 120, 11-21.

Herbst G. \& Reice S.R. 1982. - Comparative leaf litter decomposition in temporary and permanent streams in semi-arid regions of Israel. J. arid Environmts, 5, 411-424.

Hill A.R., Gardner T.J. \& Ekisola O.F. 1988. - Breakdown of gallery forest leaf litter in intermittent and perennial prairie streams. Southwestern Nat., 33, 323-331.

Ihaka R. \& Gentleman R. 1996. - R: a language for data analysis and graphics. J. comput. graphical Statistics, 5, 299-314.

Kirby J.M., Webster J.R. \& Benfield E.F. 1983. - The role of shredders in detrital dynamics of permanent and temporary streams. Pages 425-435 in Dynamics of lotic ecosystems. Fontaine R. D. \& Bartell S. M. (eds), Ann Arbor Science, Ann Arbor, Michigan, USA.

Ledger M.E. \& Hildrew A.G. 2001. - Recolonization by the benthos of an acid stream following a drought. Arch. Hydrobiol., 152, 117.

Légier P. \& Talin J. 1979. - Recolonisation d'un ruisseau temporaire et évolution du degré de stabilité de la zoocénose. Ecologia Mediterranea, 1, 149-163.

Maamri A., Bärlocher F., Pattee E., \& Chergui H. 2001. - Fungal and bacterial colonisation of Salix pedicellata leaves decaying in permanent and intermittent streams in eastern Morocco. Internat. Rev. Hydrobiol., 86, 337-348.

Maamri A., Chauvet E., Chergui H., Gourbière F. \& Pattee E. 1998. - Micro-organism dynamics on dead leaves in a temporary Moroccan river : I- Fungi. Arch. Hydrobiol., 144 , 41-59.

Maamri A., Chergui H. \& Pattee E. 1994. - Allochthonous input of coarse organic matter to a Moroccan mountain stream. Acta Oecol., 15, 495-508.

Maamri A., Chergui H. \& Pattee E. 1995. - Impact des apports végétaux allochtones sur la distribution de la faune benthique dans un cours d'eau de montagne marocain, l'Oued Zegzel. Ecologie, $26: 81-94$

Maamri A., Chergui H. \& Pattee E. 1996. - Dynamics of fine particulate and dissolved organic matter in a Moroccan mountain stream: effects of stream flow and litter quality. Polskie Archiwum Hydrobiol., 43, 401-410.

Maamri A., Chergui H. \& Pattee E. 1997a. - Leaf litter processing in a temporary Northeastern Moroccan river. Arch. Hydrobiol., 140 513-531.

Maamri A., Chergui H. \& Pattee E. 1997b. - Dynamique des apports de litière végétale et de la faune invertébrée dans une rivière méditerranéenne temporaire : l'Oued Cherraa, au Maroc. Ecologie, 28, 251-264.

Maamri A., Pattee E., Gayte X. \& Chergui H. 1999. - Micro-organism dynamics on dead leaves in a temporary Moroccan river : IIBacteria. Arch. Hydrobiol., 144, 157-175.

Marque M.C. 1986. - Etude de la structure et du fonctionnement des dayas (mares temporaires) de la Méseta occidentale marocaine. Qualité physico-chimique des eaux. Dynamique et production primaire du phytoplancton et des macrophytes. Thesis of University Paul Sabatier, Toulouse, 102 pp.

Metge G. 1986. - Etude des écosystèmes hydromorphes (dayas et merjas) de la Méseta marocaine. Typologie et synthèse cartographique à objectif sanitaire appliquée aux populations d'Anopheles labranchiae (Falleroni, 1926). Thesis of the University of Marseille, $280 \mathrm{pp}$

Meyer A. \& Meyer E.I. 2000. - Discharge regime and the effect of drying on macroinvertebrate communities in a temporary karst stream in East Westphalia (Germany). Aquat. Sci., 62, 216-231.

Meyer A., Meyer E.I. \& Meyer C. 2003. - Lotic communities of two small temporary karstic stream systems (East Westphalia, Germany) along a longitudinal gradient of hydrological intermittency. Limnologica, 33, 271-279.

Miller A.M. \& Golladay S.W. 1996. - Effects of spates and drying on macroinvertebrate assemblages of an intermittent and a perennial prairie stream. J. N. Am. Benthol. Soc., 15, 670-689.

Muñoz I. 2004. - Macroinvertebrate community structure in an intermittent and a permanent Mediterranean streams. Limnetica, 22, 107-116.

Otermin A., Basaguren A. \& Pozo J. 2002. - Re-colonization by the macroinvertebrate community after a drought period in a first-order stream (Agüera Basin, Northern Spain). Limnetica, 21, 117128.

Ramdani M. 1986. - Ecologie des Crustacés (Copépodes, Cladocères et Ostracodes) des dayas marocaines. Thesis of the University of Aix-Marseille I, 217 pp.

Robert P. \& Escoufier Y. 1976. - A unifying tool for linear multivariate statistical methods : the RV coefficient. Applied Statistics, 25, 257-265.

Ruegg J. \& Robinson C.T. 2004. - Comparison of macroinvertebrate assemblages of permanent and temporary streams in an Alpine flood plain, Switzerland. Arch. Hydrobiol., 161, 489-510.

Ryder G.I. \& Scott D. 1988. - The applicability of the River Continuum Concept to New Zealand streams. Verh. Internat. Verein. Limnol., 23, 1441- 1445.

Stanley E.H., Fisher S.G. \& Grimm N.B. 1997. - Ecosystem expansion and contraction in streams. BioScience, 47, 427-435.

Strommer J.L. \& Smock L.A. 1989. - Vertical distribution and abundance of invertebrates within the sand of a low gradient head water stream. Freshwat. Biol., 15, 263-274.

Tachet H., Bournaud M. \& Richoux P. 2002. - Introduction à l'étude des macroinvertébrés des eaux courantes. Univ. Lyon I and Assoc. Fr. Limnol. 156 p.

Tachet H., Richoux P., Bournaud M. \& Usseglio-Polatera P. 2000. Invertébrés d'eau douce, systématique, biologie, écologie. CNRS Editions, Paris. 588 p.

Tate C.M. \& Gurtz M.E. 1986. - Comparison of mass loss, nutrients, and invertebrates associated with elm leaf litter decomposition in perennial and intermittent reaches of tallgrass prairie streams. Southwestern Nat., 31, 511-520.

Ter Braak C.J.F. \& Verdonschot P.F.M. 1995. - Canonical correspondence analysis and related multivariate methods in aquatic ecology. Aquat. Sci., 57, 255-289.

Touabay M., Aouad N. \& Mathieu J. 2002. - Etude hydrobiologique d'un cours d'eau du Moyen-Atlas : l'oued Tizguit (Maroc). Annls Limnol. - Int. J. Lim., 38, 65-80.

Vannote R.L., Minshall G.W., Cummins K.W., Sedell J.R. \& Cushing C.E. 1980. - The river continuum concept. Can. J. Fish. Aquat. Sci., 37, 130-137.

Williams D.D. 1996. - Environmental constraints in temporary fresh waters and their consequences for the insect fauna. J. N. Am. Benthol. Soc., 15, 634-650. 